\title{
On the impact of online commentary in international criminal law: A vain pursuit of a Socratic ideal?
}

\author{
Dov Jacobs ${ }^{1, \star}$ and Joseph Powderly ${ }^{2}$ \\ ${ }^{1}$ Leiden University, Steenschuur 25, 2311 ES Leiden; International Criminal Court, Oude Waalsdorperweg 10, 2597 AK, \\ The Hague, The Netherlands. Email: d.l.jacobs@law.leidenuniv.nl and ${ }^{2}$ Leiden University, Steenschuur 25, 2311 ES Leiden, \\ The Netherlands. Email: j.c.powderly@law.leidenuniv.nl
}

\section{Introduction}

In the past year a series of decisions and judgments of the International Criminal Court (ICC, the Court) have given rise to immediate and heated debate online, both on blogs and on Twitter. The most prominent in this regard are relatively well-known at this point, namely: the acquittal of Jean-Pierre Bemba on Appeal, ${ }^{1}$ the acquittal of Laurent Gbagbo and Charles Blé Goudé after a no-case-to-answer procedure, ${ }^{2}$ the decision by Pre-Trial Chamber II to not authorize the opening of an investigation in the situation of Afghanistan, ${ }^{3}$ and the long awaited Appeals Chamber Judgment on the issue of head of state immunity. ${ }^{4}$ This last judgment stands out because the Court issued, a few days after the judgment, an official Q\&A, 'purely for purposes of public information', in which it not only directly addressed some of the criticism of the judgment that had been published online but also commented on the very practice of engaging in online commentary itself.

These comments by the Court were offered in response to the following question in the Q\&A: 'The judgment has generated animated discussion in [sic] blogosphere. What is the Court's view on that?'. Responding to this question, the Court criticized bloggers for 'hastily made comments' which 'fail to appreciate the totality and nuances of the Court's reasoning, and may wholly misrepresent the decision or judgment'. ${ }^{5}$ Also of note in this respect is the fact that the official spokesperson of the ICC seems to have reacted directly in the comments section of a major blog to

${ }^{\star}$ Dov Jacobs is a member of the Editorial Board, Assistant Professor of Public International Law, Grotius Centre for International Legal Studies, Leiden University and trial lawyer at the International Criminal Court. Joseph Powderly is a member of the Editorial Board and Associate Professor, Grotius Centre for International Legal Studies, Leiden University. All views expressed here represent solely the views of the authors and not the institutions they work for. The authors wish to thank Barrie Sander, Ingo Venzke, and Eric de Brabandere for comments on an earlier draft.

${ }^{1}$ The Prosecutor v. Jean-Pierre Bemba Gombo, Judgment on the appeal of Mr Jean-Pierre Bemba Gombo against Trial Chamber III's 'Judgment pursuant to Article 74 of the Statute', Case No. ICC-01/05-01/08-3636-Red, Appeals Chamber, 8 June 2018.

${ }^{2}$ ICC Press release ICC-CPI-20190115-PR1427, 15 January 2019, 'ICC Trial Chamber I acquits Laurent Gbagbo and Charles Blé Goudé from all charges'.

${ }^{3}$ Situation in the Islamic Republic of Afghanistan, Decision Pursuant to Article 15 of the Rome Statute on the Authorisation of an Investigation into the Situation in the Islamic Republic of Afghanistan, Case No. ICC-02/17-33, Pre-Trial Chamber II, 12 April 2019.

${ }^{4}$ The Prosecutor v. Omar Hassan Ahmad Al-Bashir, Judgment in the Jordan Referral re Al-Bashir Appeal, No. ICC-02/ 05-01/09-397-Corr, Appeals Chamber, 6 May 2019.

${ }^{5}$ ICC, Questions and Answers ICC-PIOS-Q\&A-SUD-02-01/19, 16 May 2019, Q\&A Regarding the Appeals Chamber 6 May 2019 Judgment in the Jordan Referral Re Al-Bashir Appeal. See Section 5 below.

( The Author(s) 2019. This is an Open Access article, distributed under the terms of the Creative Commons Attribution licence (http:// creativecommons.org/licenses/by/4.0/), which permits unrestricted re-use, distribution, and reproduction in any medium, provided the original work is properly cited. 
'defend' the Appeals Chamber Judgment. ${ }^{6}$ This immediate, official, reaction of the ICC to the 'blogosphere' highlights that international criminal law, we believe, is probably the most emblematic field where academic discussions have partly moved away from traditional means of knowledge production ${ }^{7}$ towards an increased role and significance for analysis conducted through the blogosphere and Twittersphere.

Of course, to acknowledge the growing significance of blogs and Twitter is far from revelatory. Indeed, it is by now trite to remark that the development of blogs and social media, particularly Twitter, has radically changed the way (at least certain) academics communicate in relation to their field of research. The Leiden Journal of International Law has for many years been a privileged forum in which to discuss such developments. In 2012, Larissa van den Herik reflected on the possible future interaction between blogging and traditional scholarship, recognizing the potential for a mutually beneficial interaction, noting that:

there can thus be a clear and workable division of labour between law journals and new platforms of information like blogs. This is informed by the fact that thoroughness rather than speed - characterizes law journals' contribution to the academic debate and to scientific research. In a complementary alliance, blogs offer rapid dissemination of information, whereas law journals retain a responsibility to produce analytical thinking. ${ }^{8}$

More recently, in 2018, Seline Trevisanut discussed in an editorial the involvement of scholars in discussions about current events, through the media and blogs, highlighting the benefits of immediate, contemporaneous discussions. ${ }^{9}$

In light of recent developments, we feel it is timely to reflect specifically on the current role of online commentary in international criminal law. ${ }^{10}$ It should be noted that both authors of this editorial have embraced this trend to a greater or lesser extent. Joe Powderly was one of the commentators on the blogosphere after the Bemba Acquittal, ${ }^{11}$ and is the co-editor of the PhD Studies in Human Rights blog, created by William Schabas. ${ }^{12}$ Dov Jacobs publishes extensively on his own blog ${ }^{13}$ and comments on current developments regularly on Twitter.

\footnotetext{
${ }^{6}$ The comment was made under the name 'Fadi El Abdallah', the official spokesperson of the ICC. However, the authors of this editorial are not in a position to verify whether this person effectively did post the comment. See D. Akande, 'ICC Appeals Chamber Holds that Heads of State Have No Immunity Under Customary International Law Before International Tribunals', EJIL: Talk!, 6 May 2019, available at www.ejiltalk.org/icc-appeals-chamber-holds-that-heads-of-state-have-no-immunityunder-customary-international-law-before-international-tribunals/.

${ }^{7}$ J. d'Aspremont and L. van Den Herik, 'The Public Good of Academic Publishing in International Law', (2013) 26 Leiden Journal of International Law 1.

${ }^{8}$ L. van den Herik, 'Introduction: LJIL in the Age of Cyberspace', (2012) 25 Leiden Journal of International Law 1 , at 6.

${ }^{9}$ S. Trevisanut, 'News Coverage by Scholarship', (2018) 31 Leiden Journal of International Law 741.

${ }^{10}$ This discussion should be read in the context of the broader discussion on the evolution of ICL scholarship (see S. Vasiliev, 'On Trajectories and Destinations of International Criminal Law Scholarship', (2015) 28 Leiden Journal of International Law 701), and even in the context of the broader discussion on the evolution of international law scholarship (see J. Klabbers, 'On Epistemic Universalism and the Melancholy of International Law', (2018) 29 European Journal of International Law 1057, at 1064, noting the creation of 'a new international law academic: someone who is highly competitive, who can write sexy applications about sexy topics, knows how to use Instagram and how to generate re-tweets and knows how to bring in a lot of money').

${ }^{11}$ Along with J. Powderly and N. Hayes, 'The Bemba Appeal: A Fragmented Appeals Chamber Destablises the Law and Practice of the ICC', PhD Studies in Human Rights, 26 June 2018, available at humanrightsdoctorate.blogspot.com/2018/06/ the-bemba-appeal-fragmented-appeals.html.

${ }^{12}$ Also alongside Niamh Hayes and Yvonne McDermott.

${ }^{13}$ Spreading the Jam (dovjacobs.com/).
} 


\section{The changing landscape of scholarship production}

We believe that the use of blogs and Twitter is playing a major role in changing the nature of scholarship in the field of international criminal law. As noted by Larissa van den Herik, immediate commentary on blogs raises the question of the continued relevance of the traditional case-note journal format, which would be published months after the issuance of a decision, when most interested readers will already be well informed of the contours of the decision or judgment through engagement with various online fora. ${ }^{14}$ This issue remains relevant today, especially in the field of international criminal law, where major decisions and judgments are more or less systematically dissected in blogposts within days (or even hours) of being released. However, one has to wonder whether the increased maturity of the blogging community is not also challenging more in-depth publications and discussions to some extent. Early criticism directed at blogs suggested that:

Legal blogging does not come without - serious - hazards: hasty treatment of the information, ephemeral and cursory writing, dissemination of half-baked ideas, superficiality of analyses, overly emotional reactions and all kind of impulsive expressions of thoughts which the author of a post may subsequently regret. ${ }^{15}$

This criticism, if it ever was accurate, might seem less valid today. For instance, it is worth noting that some blogs not only publish immediate reactions to current events in international criminal law, but provide more general reflections on the state of the field. For example, EJIL: Talk!, the blog of the European Journal of International Law, has published in the past few months a number of multi-part blogs by established scholars of international criminal law which explore the current difficulties faced by the ICC in a more comprehensive way. ${ }^{16}$ Other blogs, such as Justice in Conflict, or Just Security, have explored the broader political context within which the ICC operates. ${ }^{17}$ But what has driven the evolution of online commentary in the realm of international criminal law?

In reflecting on this question, there are various factors to keep in mind. First, the most prominent international criminal law bloggers have embraced the medium for more than ten years now. This means that these online commentators have, in most cases, recognized expertise in international criminal law that allows them to provide relevant analysis within a short window of time. Who would challenge the principled competence for example of Marko Milanovic at EJIL: Talk!, Alex Whiting at Just Security, Kevin Jon Heller at Opinio Juris or Milena Sterio and Parisa Zangeneh at IntLawGrrls? The usual suspects of online commentary do not reinvent the wheel with each new blogpost. On the contrary, they rely on their acquired knowledge and expertise to try and provide the most relevant observations possible.

Second, these authors often build on their own previous blogs on particular issues, which reduces the impression that individual blog posts are stand-alone reactions to an isolated decision. Over the years, most regular bloggers have followed extensively certain questions or themes and developed over time an in-depth analysis that is not very different, when blog posts are read together, from a journal article. Examples abound in this respect: Mark Kersten, at Justice in Conflict, has provided a diverse and complex reflection on the ICC's legitimacy deficit. Alex Whiting has triggered an ongoing conversation about prosecutorial strategies. Dov Jacobs and

\footnotetext{
${ }^{14}$ See van den Herik, supra note 8 , at 6.

${ }^{15} \mathrm{~J}$ d'Aspremont, 'In Defense of the Hazardous Tool of Legal Blogging', EJIL: Talk!, 6 January 2011, available at www. ejiltalk.org/in-defense-of-the-hazardous-tool-of-legal-blogging/.

${ }^{16}$ Most notably by Douglas Guilfoyle, Sergey Vasiliev, Dov Jacobs, and Kai Ambos.

${ }^{17}$ The same is true of Spreading the Jam, the blog of one of the authors, Dov Jacobs, which regularly offers broader reflections on the impact of a particular decision on the work and perception of the Court.
} 
Kevin Jon Heller have followed the evolution of the Court's case law on certain topics for years now, be it immunities or complementarity.

Third, international criminal law bloggers have developed specific skills in analysing complex decisions quickly and efficiently (even if understanding the minutiae of these decisions takes longer), and these skills should not be underestimated. In the same way that writing a convincing journal article requires a certain type of talent, so does the production of a blogpost, in terms of presenting ideas in a clear and succinct way. In this sense, contrary to a commonly shared opinion, there is no reason that blogging should not be considered as one criterion for career advancement, along with other more traditional criteria. The evolution of online commentary is such that, while of course short blog posts will never replace traditional scholarship in terms of providing in-depth analysis accompanied by extensive supporting references, it is harder to claim that the two media operate side-by-side with no possibility for friction.

One aspect of the impact of new practices on traditional scholarship that is rarely discussed is how these practices highlight some of the inherent drawbacks of traditional scholarship. Specifically, while traditional scholarship has the benefit of hindsight, the editing and production process takes time and often does not allow for articles to be published within a reasonable timeframe after a particular issue has emerged. Moreover, while comprehensive referencing in support of one's ideas is arguably traditional scholarship's greatest virtue, there is also the inevitable risk that argumentation gets drowned out by a cacophony of needless academic name-dropping. ${ }^{18}$ In the worst cases, articles are reduced for the most part to being glorified literature reviews in order to satisfy the codes of our trade.

\section{Criticisms of blogging}

One criticism of blogging that has recently emerged online and in informal discussions is that the space is occupied by the 'loudest' commentators, to the detriment of 'weaker' voices. This is true to some extent, but it is difficult to see it as a criticism of blogging as such. Indeed, all epistemic communities function on recognition and hierarchies. This is as true of blogging as it is of traditional scholarship; in fact, when it comes to hierarchies, one could consider that new media like blogs and Twitter are arguably more democratic than other media. Indeed, over the years, some talented young scholars have made a name for themselves on blogs and Twitter in ways that traditional scholarship might not have allowed in such a short timeframe. That said, we must acknowledge the regrettable, but inescapable, reality that ICL commentary on blogs and Twitter is for the most part a male dominated environment.

Another criticism of blogging that has been put forward (which is paradoxically the exact opposite to the previous criticism) is that anyone can do it and that there is no quality control. This can be contrasted with the view that traditional scholarship does provide such quality control and certification. ${ }^{19}$ However, one can wonder how true this is today. On the one hand, blogs and Twitter provoke immediate reactions from colleagues, usually experts in the field of international criminal law, with the consequence that a mistake or an oversight will be immediately pointed out. In addition to that, as noted previously, the blogosphere and Twittersphere are far more organized than they might first appear. Noteworthy in that respect is the fact that some of the major international law blogs have become increasingly professionalized in their modes of functioning, with, for example, the creation of an editorial board similar to traditional law journals, ${ }^{20}$ and external funding. More generally, if one spends a little time online, it becomes quickly apparent what blogs or Twitter accounts will provide the

\footnotetext{
${ }^{18}$ Usually this is done through a generic reference in the footnote to a commonly accepted seminal article on a particular issue, with no particular reference to a particular page. On this, see Professor Famous, 'Really Important Article', Really Important Publication, 25 years ago, any page will do.

${ }^{19}$ See d'Aspremont and van Den Herik, supra note 7 , at 3.

${ }^{20}$ See, for example, Lawfare (www.lawfareblog.com/masthead).
} 
most accurate and relevant commentary. On the other hand, the proliferation of traditional academic publishers and publications means that the idea that an academic publication is necessarily a sign of quality or worthiness is far from obvious.

Ultimately, with blogging, like with traditional legal scholarship, recognition is built over time, certain blogs acquiring a certain reputation for quality which will lead to more people reading them. What we do as consumers of legal knowledge is exercise judgment when deciding what to read or not to read, based on prior experience. The difference between blogging and traditional legal scholarship is that the latter obviously has a head start in the recognition process, but it is difficult to see how the underlying logic is not the same.

Another point that has often been made in relation to blogging (and Twitter) is aptly summarized by Seline Trevisanut:

You want to possibly set the terms of the discussion. For that, you need to be the first mover, and you need to be fast in producing your contribution. Subsequent posts and comments will necessarily interact with the first one, supposing that it meets a minimum level of quality, of course. $^{21}$

While this 'rush' to have a first post on an issue is most certainly a reality, it is not necessarily a negative aspect per se if it indeed meets the required level of quality. A poor or inaccurate blogpost will not receive wide attention, even if it is the first to be published. Also, such a statement should not blind us to the reality of traditional academic publishing strategies. Authors vie for attention and recognition whatever the medium of communication used. As a scholar, you want to be the first to publish a book or an article on a new international court, or a new legal concept in international criminal law. This is a good thing. Academics, by definition, have the inherent belief that they have new and original ideas (if not, why bother?), and a natural corollary of this is the desire to have these ideas publicized and attributed to themselves. In this sense, while traditional scholarship follows a slower pace, its underlying rationale is not very different than that of the blogosphere. $^{22}$

\section{Benefits}

The most obvious benefit of new media of communication is the immediacy of access to information about recent developments in international criminal law, but there are other benefits that flow from this immediacy. For instance, there is a form of democratization of access to information, which is not necessarily true with traditional legal scholarship. In this sense, the development of blogging and Twitter are part of the general discussion about open access to knowledge which major law journals, including the Leiden Journal of International Law, have been having for some years now, and will likely continue to have in the future.

This facilitation of access to information relates not only to scholarly production stricto sensu. For example, the development of live-tweeting (the practice of commenting an event on Twitter as it is unfolding) allows for a dissemination of information far beyond the immediate audience of the event. Such practice has become particularly common in relation to academic conferences and it is not infrequent for scholars present at the conference to debate, on Twitter, papers delivered with scholars who could not attend. ${ }^{23}$

Moreover, blogs and Twitter create the conditions for immediate, and often fruitful dialogue on ICC-related matters. Recent judgments of the Court saw days-long discussions on specific, sometimes

\footnotetext{
${ }^{21}$ See Trevisanut, supra note 8 , at 743 .

${ }^{22} \mathrm{On}$ the competition between international scholars seen through a semantic prism see J d'Aspremont, 'Wording in International Law', (2012) 25 Leiden Journal of International Law 575.

${ }^{23}$ Thank you to Barrie Sander for pointing out this benefit of live tweeting ... during a conversation on Twitter.
} 
technical points of procedure or law, in a truly collective endeavour. How remarkable this practice is should not be understated: academics (by definition engaged in the competition for recognition discussed above), are lending themselves, particularly on Twitter, to an exercise whereby they agree to 'pool' their expertise, publicly discuss an issue, to often reach a conclusion that cannot meaningfully be attributed singly to any one person who participated in the discussion. In other words, Twitter (at least occasionally) provides a welcome space of selfless intellectual exchange, which is at odds with the jealous guarding of innovative ideas that is usually associated with the pursuit of academic success. This can be seen as a perfect illustration of what Jean d'Aspremont described as one possible benefit of development of 'new means of transfer of knowledge': the fact that 'legal scholars of the 21st century have grown more faithful in the Socratic virtues of the exchange of ideas which they now see as instrumental in the mutual development and sharpening of legal thinking as a whole. ${ }^{24}$

In addition, these new practices also open entirely new perspectives for interdisciplinary dialogue. This dialogue is a key aspect of the intellectual core of the Leiden Journal of International Law, as has been demonstrated by the diversity of its publications in international criminal law and through the views expressed in a number of editorials, most recently by Joseph Powderly. ${ }^{25}$ The proliferation of online commentary has been accompanied by a noticeable breaking down of disciplinary barriers, with experts from various disciplines (law, international relations, sociology, anthropology, etc.) directly interacting on the various aspects of a decision, with, as a result, an immediate enrichment of the conversation.

Linked to this breaking down of disciplinary barriers is a breaking down of professional barriers. International criminal law is a field of international law with noticeable porousness between various epistemic communities (more particularly those of scholars, practitioners and NGOs), both in terms of membership and modes of communication. While the bringing together of these epistemic communities did not wait for online modes of communication to exist, and has always been promoted in various fora, such as conferences or edited volumes of journals, online media, especially Twitter, have created the conditions for a direct and immediate dialogue between the members of these professional groups in a way that side-by-side chapters in an edited volume cannot.

Finally, linked to the previous two benefits, online commentary, especially on Twitter, creates new communities of thought outside of the conference trail, which is traditionally where people meet and create professional bonds. One of the authors of this editorial interacts daily with scholars and practitioners from around the globe, sometimes even creating personal relationships, discussing and developing projects without having ever met in person. This is another example of the democratizing process fostered by new technologies: getting to form new professional connections without spending hundreds of euros to attend conferences around the world.

\section{An unexpected 'official' recognition by the ICC}

As alluded to in our Introduction, on 16 May 2019, a few days after the delivery of the Appeals Chamber Judgment on Head of State immunities at the ICC, the communication services of the Court issued a Q\&A about the judgment which directly responded to the online commentary. ${ }^{26}$ The Q\&A picks up on some of the main criticisms of the judgment that were published online and provides what it considers to be an adequate answer. The fact that the Court felt the need to directly respond to critics of the judgment is already a noteworthy event. This means that someone

\footnotetext{
${ }^{24}$ See d'Aspremont, supra note 15.

${ }^{25}$ J. Powderly, 'International Criminal Justice in an Age of Perpetual Crisis', (2019) 32 Leiden Journal of International Law 1.

${ }^{26}$ For a comprehensive analysis of the Q\&A see D. Jacobs, 'Q\&A regarding the "Q\&A REGARDING APPEALS CHAMBER'S 6 MAY 2019 JUDGMENT IN THE JORDAN REFERRAL RE AL-BASHIR APPEAL”, Spreading the Jam, 17 May 2019, available at dovjacobs.com/2019/05/17/qa-regarding-the-qa-regarding-appeals-chambers-6-may2019-judgment-in-the-jordan-referral-re-al-bashir-appeal/.
} 
at the Court considered that these online comments about the judgment needed to be addressed in order to alleviate the concerns a broader audience might have about the judgment. In other words, the Court, in issuing the Q\&A is acknowledging, if not the actual power of blogs, at a minimum its own belief that blogs and Twitter are important providers of information about the work of the Court.

However, the Q\&A does not stop there, and suffice it to say that the recognition afforded the blogosphere and Twittersphere is not entirely benign. Indeed, the Q\&A not only answered the critics of the judgment, but directly challenges these commentators themselves, in ways which are particularly relevant for our discussion:

In the era of social media, it is hoped that observers would properly study the Court's judgments and decisions before rushing to comment on them. Hastily made comments, particularly when made before the commentator has even read the judgment in question, will fail to appreciate the totality and nuances of the Court's reasoning, and may wholly misrepresent the decision or judgment. At the same time, those first comments appearing on social media frequently tend to dominate the ensuing discussion as they are tweeted and retweeted, regardless of their accuracy. ${ }^{27}$

The Q\&A then goes on to specifically call on the ethical obligations of 'lawyers' to 'exercise particular caution and remain mindful of the cardinal principles that guide the conduct of lawyers, including that of honesty, integrity and fairness'. It concludes this lesson to commentators in the following way: 'It does not mean that judges and courts may not be criticised. It only means that they be criticised fairly. There is an ethical obligation to reflect facts and circumstances accurately and fairly.'

On first analysis, one could consider that, in acknowledging blogs and Twitter, the Court is showing an understanding of how these modes of communication are changing the way decisions of international tribunals are being publicized, commented on and generally received by broader target audiences ${ }^{28}$ and, more particularly for the purposes of our discussion, how followers of the Court will facilitate information relating to the Court. However, rather than reflect on this changing landscape and critically assessing what it means for the way the Court interacts with these communities, the decision was taken ${ }^{29}$ to push back against the practice.

Indeed, the Q\&A is, among other things, quite an extraordinary and unwarranted attack on the professionalism and competence of many of those who commented on the judgment following its issuance. The implied suggestion is that those who disagreed with the judgment either did not read it and/or did not understand it. This suggestion is particularly disturbing when one considers that among many competent international lawyers who initially reacted to the judgment, was Dapo Akande,$^{30}$ one of the most influential international scholars when it comes to the question of immunities in international law and international criminal law. In casting such aspersions, the Court also shows a misunderstanding of the way social media functions today: tweets create a unique opportunity for a rich debate about issues. The exchanges that took place immediately after the judgment followed exactly this pattern, with numerous discussions ensuing between critics and defenders of the judgment, and even between critics of the judgment. The idea that people on Twitter are uncritical sheep who simply retweet other people's comments

\footnotetext{
${ }^{27}$ ICC, Questions and Answers, QઐA Regarding the Appeals Chamber 6 May 2019 Judgment in the Jordan Referral Re Al-Bashir Appeal, ICC-PIOS-Q\&A-SUD-02-01/19_Eng, May 2019.

${ }^{28} \mathrm{On}$ the broader issue of how international decisions are received outside the courtroom see B Sander, 'History on Trial: Historical Narrative Pluralism Within and beyond International Criminal Courts', (2018) 67 ICLQ 547.

${ }^{29}$ It is not clear, unfortunately, by whom this decision was taken. The Q\&A purports to answer the question 'What is the Court's view on [online commentary]?', but without making clear which organ of the Court was responsible for drafting the content or whose views are represented therein. The ICC Spokesperson is employed by the Registry, but the level of detail regarding the legal reasoning would suggest the involvement of Chambers staff.

${ }^{30}$ See Akande, supra note 6.
} 
'regardless of their accuracy' is far from accurate. As regards fairness, there are two difficulties with the statement of the Court. Firstly, there is no real explanation of why, in fact, criticism of the Court should be in any way judged along standards of 'fairness' ${ }^{31}$ Criticism should be judged by standards of accuracy and methodological rigour, which are professional obligations on the part of the commentators and have nothing to do with the Judges of the ICC, to whom no obligation of 'fairness' is necessarily owed. Secondly, there is of course no explanation of what is to be considered as 'fair' criticism. In the absence of clear guidelines on this, is it easy to conclude that 'fairness' might be equated simply with 'agreement'.

\section{Conclusion: Critique as a shared value of the academic endeavour}

The Court's Q\&A about the immunities judgment, beyond the immediate difficulties that it raises, is part of a broader trend that should be concerning for all scholars working in the field of international criminal law, irrespective of their preferred method of communication. There is today a tendency among a number of staunch 'defenders' of the ICC and more generally of the international justice project to view any critical discussion of the work of the Court as an 'attack' on the institution that will weaken it. Critics are summoned to support the Court, to be 'constructive' and to limit themselves to what has been aptly called an 'effectiveness critique', ${ }^{32}$ i.e., a critique aimed at making the project better - so-called 'criticism with a purpose. ${ }^{33}$ The underlying assumption here is that the ICC is, by definition, worthy of moral (and therefore intellectual) support, given its lofty ambition to end impunity. On one level, this perceived tension between support and critique is understandable in a field that is heavily emotionally and morally charged. However, this invitation to moderate criticism/critique is problematic on a number of levels.

The fact that the ICC is so sensitive to what it perceives as 'negative' criticism is not a good indication of a mature institution. A mature institution should be willing to hear even the harshest critics of its work, even if it chooses not to engage with all of them. Some criticism of the Court is, indeed, possibly misguided, to the extent that it stems from a misunderstanding of what a criminal court can actually achieve on a societal level when involved in a post-conflict setting. ${ }^{34}$ But generally, it should no longer be possible for the ICC, 26 years after the modern rebirth of international criminal law, 17 years after it started its operation, to use its alleged 'youth' and 'growing pains' (expressions one still hears regularly in discussions about the ICC) to shield itself from criticism, some of which relate to structural problems at the Court that have existed from its very inception.

Calling on observers of the Court to be reflexively supportive of its work has the effect of side-lining legitimate concerns raised in relation to the project of international criminal justice as a whole. Such concerns are frequently raised by scholars who could hardly be considered as anti-human rights or pro-impunity. For many years now, including within the LJIL, ${ }^{35}$

\footnotetext{
${ }^{31}$ Rather ironically, the Court explains, in a document where it directly responds to specific criticisms, that rules that impose 'special caution on criticism of judges and courts' exist 'not because it is wrong to criticise them, but because they are generally not in a position to respond to specific criticisms'.

${ }^{32}$ C. Schwöbel, 'Introduction', in C. Schwöbel (ed.), Critical Approaches to International Criminal Law (2014), 1, at 3.

${ }^{33}$ As expressed by an ICC Judge recently in The Hague.

${ }^{34} \mathrm{~A}$ different debate, which is beyond the scope of this editorial, is the fact that this misunderstanding is due in part to public pronouncements of Court officials themselves in relation to the positive impact of the ICC on broader objectives such as peace, truth, and reconciliation, thus creating expectations that will likely never be met. This question is the object of regular online commentary. More recently, see Mark Kersten discussing the balance to be struck between aspirational goals of the ICC and the realistic management of expectations (M. Kersten, 'Is the International Criminal Court Still an Aspirational Institution? Can it Be?', Justice in Conflict, 22 May 2019, available at justiceinconflict.org/2019/05/22/is-the-international-criminal-courtstill-an-aspirational-institution-can-it-be/).

${ }^{35}$ T. Krever, 'International Criminal Law: An Ideology Critique', (2013) 26 Leiden Journal of International Law, 701; I. Tallgren, 'We Did It? The Vertigo of Law and Everyday Life at the Diplomatic Conference on the Establishment of an International Criminal Court', (1999) 12 Leiden Journal of International Law 683.
} 
scholars have questioned the underlying assumptions of international criminal justice, both from a conceptual and an empirical perspective and challenged the idea that universal justice is the best way to deal with mass atrocities in particular situations. These voices should not be silenced, either in blogs or in traditional scholarship.

The expectation that scholars working in international criminal law, and more specifically on the ICC, should tailor their criticism in a way that it is not perceived as undermining the moral claims of the ICC is problematic from an intellectual perspective. As legal scholars, we have a professional obligation of intellectual honesty in the conduct of our research. The fact that we have moral or ethical preferences in relation to a particular issue should not seep into our legal methodology, lest we cross the border between scholarship and activism. In this sense, the authors of this editorial do not believe that legal scholarship in the field of international criminal law should unquestioningly aim at supporting the system or making the system better. In fact, we believe that research teleologically guided in this way is more likely to suffer from lack of methodological rigour, because the scholar will more likely be trying to 'fit' the outcome of his or her research in a predetermined conclusion, to the point of denying any other reasonable legal understanding of an issue and, as a consequence, denying that any reasonable disagreement can be expressed.

Ultimately, beyond the discussion on the relationship between traditional scholarship and new modes of communication, what should continue to unite the epistemic communities involved in the study of international criminal law is an attachment to shared values of dialogue, intellectual honesty, methodological rigor and, above all, freedom of expression. These values are crucial to guarantee our independence and academic freedom and any threat to any of these values should be combatted vigorously by everyone, both online and in traditional scholarship, as a threat to the epistemic community as a whole.

Cite this article: Jacobs D and Powderly J (2019). On the impact of online commentary in international criminal law: A vain pursuit of a Socratic ideal?. Leiden Journal of International Law 32, 615-623. https://doi.org/10.1017/S0922156519000414 